coccus faecalis (4). Mixed infections (including Pseudomonas, Staphylococcus aureus, Klebsiella, and Proteus spp.) were present in 21 urines from patients with gross urological abnormalities. In 13 instances urine samples were collected following the administration of antibiotics.

All samples were transferred to the laboratory immediately after collection, and bacterial counts carried out by the surface plating method. Part of the sample was immediately refrigerated, while the remainden was incubated at $37^{\circ} \mathrm{C}$. overnight. At the end of this period further bacterial counts were carried out, and the creatinine content of both the refrigerated and incubated samples was measured on the Technicon auto-analyser.

In 12 urines which contained $10^{8}$ organisms/ $\mathrm{ml}$., and in nine urines from treated patients, the counts did not rise detectably on incubation. Otherwise, following overnight incubation the bacterial counts rose to $10^{*}$ or more per ml., representing a rise of more than 1,000 -fold in 16 urines, 100 -fold in nine, and 10 -fold or more in the remainder. Urinary crcatinine concentrations ranged from 14 to $236 \mathrm{mg} . / 100 \mathrm{ml}$. In none of the 90 samples examined was there any change in urine creatinine content outside the analytical error of the method.

The results of these studies thus clearly show that over a wide range of creatinine concentrations bacterial multiplication within the urine over a period of up to 24 hours has no effect on urinary creatinine content. We have therefore concluded that estimations of urinary creatinine for clearance or other purposes are not invalidated by the presence of bacteria in the sample.-We are, etc.,

W. R. Cattell.
J. M. Sardesoiv.
E. Hutchinson.
F. O'Grady.

St. Bartholomew's Hospital, F. O'GRADY.

REFERENCES 1 Healy, J. K., American foumal of Medicine,

2 Relman, A. S., and Levinsky, N. G., in Disease L. G. Welt, 1963, p. 80 . Boston, Little Brown and Co.

\section{Manson and Malaria}

SIR,-The article on Aberdeen Medical School (28 June, p. 816) contains the statement that Sir Patrick Manson discovered the cause of malaria. This distortion of medical history ought not to be allowed to pass.

The malaria parasite was discovered by Alphonse Laveran in 1880 and its transmission by a mosquito by Ronald Ross in 1897. Manson must be given credit for the mosquito-malaria theory, which he formulated and put forward in 1894 and again in 1896, and which guided and stimulated Ross. It remained, however, only a theory until Ross and later workers actually transmitted the malaria parasite by the bite of a mosquito.

The scepticism with which the mosquitomalaria theory was received is illustrated by a story which Sir Patrick's son-in-law, the late Sir Philip Manson-Bahr, used to tell. One day a colleague caught sight of Manson on the other side of the street and remarked to his companion: "Do you know who that is ? That's mosquito Manson," and tapped his head significantly.

Conclusive evidence of the part played by the mosquito was given by the experiments devised by Manson in 1900, when it was shown that it was possible to escape infection in a highly malarious locality in Italy by living in a dwelling protected by wire gauze, and secondly that mosquitoes fed in Rome on patients suffering from malaria infected two persons in London by their bites.

I do not consider it necessary to give any references to the literature as the story is too well known.-I am, etc.

\section{Whitehead, \\ Co. Antrim.}

H. G. Calwell.

\section{Paraneoplastic Hypercalcaemia and Renal Malignancy}

SIR,-Paraneoplastic hypercalcaemia has been found in association with a wide variety of malignant processes. ${ }^{1} \quad$ Cytological specificity appears to exist in certain of the paraneoplastic syndromes. ${ }^{2}$ The present communication considers the possibility of a renal cellular specificity with respect to the syndrome of paraneoplastic hypercalcaemia.

In the 19 cases of renal carcinoma reported in association with "pseudohyperparathyroidism," 11 indicate cell type. Of these, $77 \%$ are cells with a clear cytoplasm, and the remainder squamous or transitional cell carcinomas of the renal pelvis. These data suggest the importance of the clear cell in its association with the syndrome, considering that the clear cell renal-cell carcinoma is found in but $40 \%$ of renal malignancies. ${ }^{3}$ The tumour composed of renal cells with clear cytoplasm has already been signalled in association with paraneoplastic erythrocytosis (4 January, p. 51). However, among the 83 cases reporting that syndrome which presented cell type, no tumour of the renal pelvis was noted.

Thus there appears to be a tendency for the clear cell renal-cell carcinoma and the transitional or squamous cell carcinoma of the renal pelvis to be associated with "pseudohyperparathyroidism" more frequently than the cell with granular cytoplasm, Wilms's tumour, or other malignant renal lesion.-I am, etc.,

\section{Michael A. Sperber. \\ Harvard Medical School Beth Israel Hospita
Boston, U.S.A. \\ REFERENCES}

O'Grady, A. S., Morse, L. J., and Lee, J. B.,
Annals of Internal Medicine, 1965, 63, 858. Lancet, 1964, 1, 317.

3 Murphy, G. P., and Mostofi, F. K., fournal of Urology, 1965, 94, 48.

\section{Vitamin $C$ and the Elderly}

SIR,-We agree with Drs. J. C. Brocklehurst and L. L. Griffiths (28 June, p. 824) that daily doses of ascorbic acid larger than the 40- and 80-mg. doses we chose (17 May, p. 416) would accelerate the rise in leucocyte ascorbic acid concentration and are to be recommended for the correction of gross deficiency. Bowers and Kubik ${ }^{2}$ reported in 1965 that a $120-\mathrm{mg}$. daily supplement of ascorbic acid raised initially low leucocyte concentrations of ascorbic acid to levels above those of younger, healthy people in four weeks.

Our supplementation doses were chosen to be of the same order but in excess of the B.M.A.'s 30 mg. $^{2}$ and the then United States's $70 \mathrm{mg}^{3}$ (now $60 \mathrm{mg}$. for males and $55 \mathrm{mg}$. for females $^{4}$ ) recommended daily dietary allowances. It was therefore surprising that these nutritional levels of supplementation were inadequate to produce a rapid response in our group of elderly subjects. A reduced renal threshold or an increased requirement for ascorbic acid could explain the slow leucocyte response. More investigation is necessary, including more study of the clinical significance of biochemically subnormal levels of ascorbic acid in the elderly, especially as the unsupplemented control group of Drs. Brocklehurst and Griffiths ${ }^{5}$ showed an $87 \%$ rise in the mean leucocyte ascorbic acid concentration to a level typical of young, healthy individuals during the first six months of the study.-We are, etc.,

West Middlesex Hospital,

JAMES ANDREWS.

Middx.

M. BROOK,

Manager, Basic Research Department,
Beecham Products U.K.

Brentford,
Middx.

REFERENCES

Bowers, E. F., and Kubik, M. M., British fournal of Clinical Practice, 1965, 19, 141.

British Medical Association, Report of the Committee on Nutrition
Medical Association.

National Research Council, Recommended Dietary Allowances, 1964, 6th edition, Publication No. National Research Council, Recommended Dietary Allowances, 1968, 7th edition, Publication No. Brocklehurst, J. C., Griffiths, L. L.' Taylor,
G. F., Marks, J., Scott, D. L. and Blackley, J., Gerontologia Clinica, 1968, 10, 309.

\section{How Many Authors Can Collaborate?}

SIR,-The recent paper "Liver Transplantation in Man-III ..." (5 July, p. 12) appears under the authorship of no fewer than 17 authors-surely a near-record? It is my experience that such therapeutic committees merely provide opportunities for their members to add to the number of their publications.

One man may write a paper ; two may, with difficulty, collaborate; three may conceivably achieve something without violence to conscience: but that 17 should agree passes the bounds of credibility or credulity.

As a convinced non-collaborator, my opinion is open to criticism; but 17 ...I am, etc.,

Ipswich and East Suffolk Hospital,

J. W. Dickson.

Ipswich, Suffolk.

\section{Disodium Cromoglycate in Exercise-induced Asthma}

SIR,-Various theories have been suggested to explain the bronchoconstriction that follows exercise: (1) a nervous reflex stimulated by hyperventilation and the movement of the bronchial walls; (2) the release of a humoral substance during exercise such 